\title{
Larval morphology and biology of two species of Aphodius (Plagiogonus) from the Iberian Peninsula (Coleoptera: Scarabaeidae: Aphodiinae)
}

\author{
José R.VERDÚ and EduARDo GALANTE \\ Centro Iberoamericano de la Biodiversidad (CIBIO), Universidad de Alicante, E-03080 Alicante, Spain; \\ e-mail: jr.verdu@carn.ua.es; galante@carn.ua.es
}

Key words. Scarabaeidae, Aphodius, larvae, life history, morphology, Iberian Peninsula

\begin{abstract}
The larval morphology of Aphodius (Plagiogonus) nanus Fairmaire, 1860 and A. (P.) arenarius (Olivier, 1789) are described and redescribed, respectively. The common characters of both species, and the specific diagnostic characters are provided and discussed. The most important morphological characters of the larvae of Plagiogonus Mulsant, 1842 are the longitudinal alignment of the anterior setae of the stipes, the spatulate form of the posterior-lateral setae of the glossae of the hypopharynx, the slight development of the anal lobe slit, the form of the epitorma of the epipharynx, the slight sclerotization of the pternotormae and the relative length of second antennal segment. A key to the larvae of both species of Plagiogonus is presented along with life history data and the preferred food of these species. This study shows that $A$. arenarius and $A$. nanus feeding habits are closer to saprophagy than to coprophagy.
\end{abstract}

\section{INTRODUCTION}

The entire larval development of Aphodius Illiger, 1798 typically takes place in dung. Most species oviposit single eggs in fresh dung and some species construct primitive nests in the soil under the dung (Cambefort, 1991; Barbero \& Palestrini, 1995). Other species have trophic habits that are closer to saprophagy than coprophagy and tend to lay eggs in the interface between the trophic resource (dry dung, accumulations of manure, decomposing leaves, etc.) and the soil. In this case, the larvae never enter the dung (Lumaret \& Stiernet, 1984; Verdú et al., 1997; etc.). Some species lay small compact groups of eggs directly into the soil as is typical of some saprophagous Aphodiinae such as Eupariini and Psammodiini (Lumaret \& Lavalette, 1996; pers. obs.).

Aphodius (Plagiogonus) arenarius (Olivier, 1789) is a relatively rare species, mostly occurring in cold areas of the Palaeartic (Baraud, 1977; Lumaret, 1978, 1990; Verdú, 1998). It is widespread throughout Europe, the Caucasus, Kazakhstan and Turkestan. In the Iberian Peninsula, A. arenarius has only been collected in high mountains and at present its southernmost limit is North of the Province of Alicante, Spain (Verdú, 1998). Martynov (1998) describes its larval morphology but omits some relevant characters. In the Iberian Peninsula, Aphodius (Plagiogonus) nanus Fairmaire, 1860 is rarer than the former species and its biology, ecology and larval morphology are unknown. Its distribution ranges from North Africa to the Middle East. In Europe, A. nanus is only found in the southern half of the Iberian Peninsula (Báguena, 1967; Baraud, 1977; Verdú, 1998).

\section{MATERIAL AND METHODS}

This study was carried out at different localities in the Province of Alicante, southeastern Spain. Pitfall traps (Mena et al., 1989) baited with cattle dung were used to monitor the activity of adults of $A$. arenarius from April 1992 to April 1993 at Font Roja Nature Park (UTM: 30SYH1481; 1,350 m a.s.l; supramediterranean bioclimate) and from January 1995 to January 1996 at Sierra de Onil (UTM: 30SYH0380; $1,206 \mathrm{~m}$ a.s.l.; supramediterranean bioclimate). Portions of partially buried pieces of wood and pitfall traps baited with dog faeces were used to monitor the activity of adults of A. nanus from January 1996 to January 1997 at "El Garbinet" (UTM: 30SYH2049; 50 $\mathrm{m}$ a.s.1.; termomediterranean bioclimate). All pitfall traps were baited fortnightly. Larvae and adults of both species were also collected directly from different droppings, manure, cut wood, carrion, decomposing leaves, etc.

For the purpose of laboratory studies, a total of 10-20 adult specimens of each species were kept in cylindrical plastic breeding cages ( $20 \mathrm{~cm}$ high, $10 \mathrm{~cm}$ diameter) with moistened soil and crumbled dry rabbit dung. The lid had an opening $(6 \mathrm{~cm}$ diameter) covered with gauze screen. A total of six breeding cages were kept in a climatic chamber maintained at $25: 20^{\circ} \mathrm{C}$ (L : D), $80: 85 \%$ RH (L : D), and a photoperiod of $15: 9$ (L : D). The breeding cages were examined and results recorded weekly. Throughout the study period complementary data were obtained in the field.

Voucher specimens are deposited in the Entomological Collection of the Universidad de Alicante (CEUA), Alicante, Spain. The morphological terms of Ritcher (1966), Kim \& Lumaret (1988) and Verdú \& Galante (1997) were used to describe the larvae.

\section{RESULTS}

\section{Subgenus Plagiogonus Mulsant, 1842 \\ Larval description (third instar)}

Body. C-shaped, arched at the level of 5th abdominal segment (Figs 1, 13). Small species: Length of body $5.23-5.43 \mathrm{~mm}$; width of thorax $0.83-0.93 \mathrm{~mm}$; maximum width of abdomen $1.08-1.15 \mathrm{~mm}$.

Head. Cranium straw coloured, transverse (width: 0.78-0.84 mm, length: $0.55-0.63 \mathrm{~mm}$ ) (Figs 2, 14), bearing on each side: one seta on anterior frontal angle, 

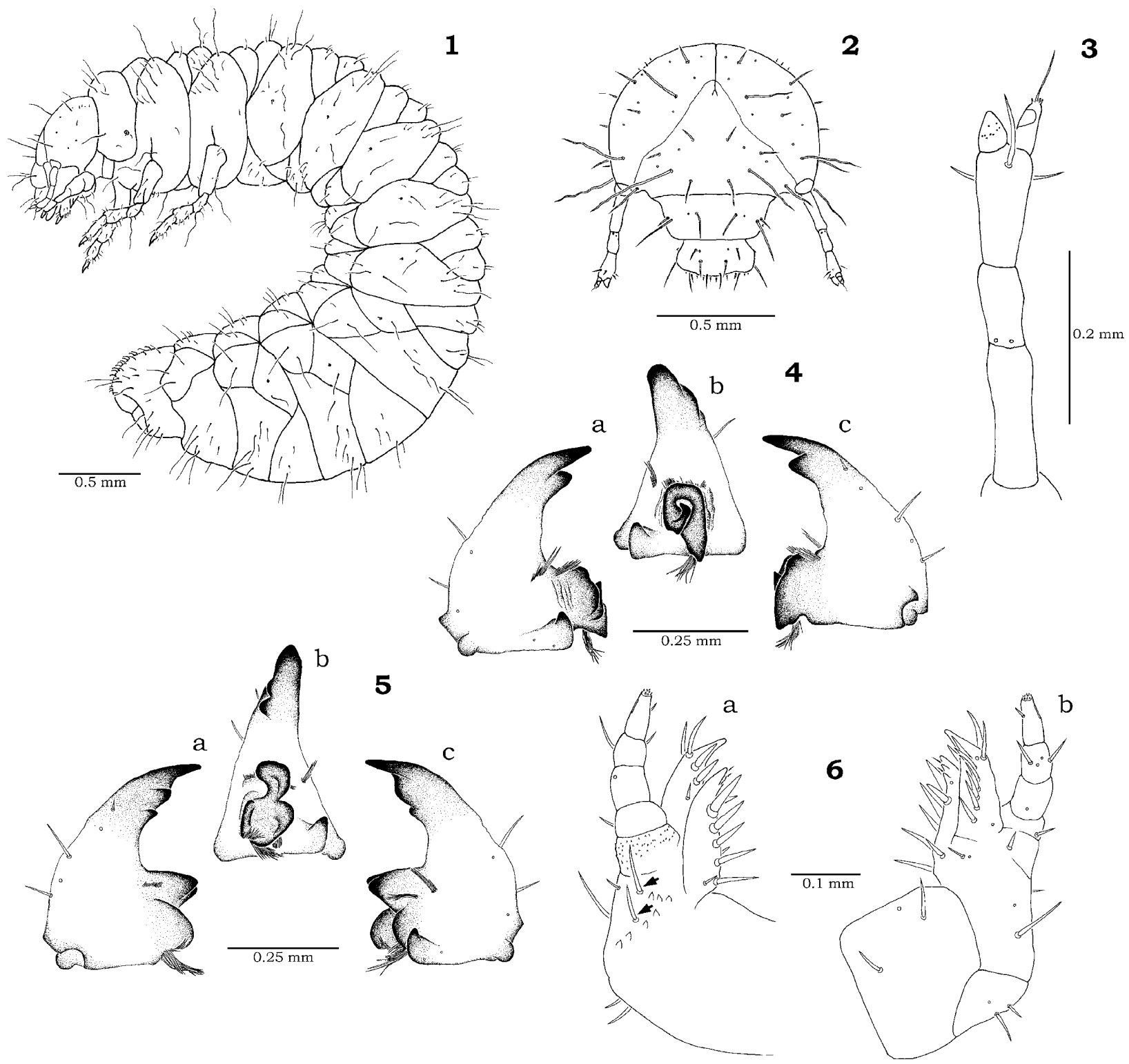

Figs 1-6: Aphodius arenarius. 1 - third-instar larva, left lateral view; 2 - head, frontal view; 3 - left antenna; 4 - right mandible: a - ventral, $\mathrm{b}$ - molar and $\mathrm{c}$ - dorsal view; 5 - left mandible: $\mathrm{a}$ - ventral, $\mathrm{b}$ - molar and $\mathrm{c}$ - dorsal view; 6 - left maxilla: $\mathrm{a}$ - dorsal (anterior setae of stipes marked by arrows) and $b-$ ventral view.

one longer seta on the lateral frontal part, one short seta on anterior frontal region and two posterior lateral setae on frontal region. Epicranial region with 4 dorsoepicranial setae, 6-8 lateral setae and 3 or 4 microsetae posteriorly. Epicranial suture present, slightly surpassing frontal suture. Clypeus transverse, with one anterior seta and two lateral setae of different size on each side; the outer seta much shorter than the inner. Labrum trilobed, with one pair of internal setae and, posteriorly, one pair of long lateral setae; lateral lobe with one seta, middle lobe with 4 anterior setae and two posterior setae. Antennae 4-segmented (Figs 3, 15); first antennal segment 1.5-2 times the length of second. Second segment with 5 macrosensilla; third with one ring of 5 setae and one welldeveloped cone-shaped sensorial structure; fourth short, with an inner sensorial area extended to dorsal and ventral surfaces; apex with one ring of 5 setae, one of which is longer and flagelliform. Mandibles (Figs 4, 5, 16, 17) asymmetrical, with 3 dorso-external setae and two microsensilla between setae. Right mandible: $S_{1}$ and $S_{2}$ teeth fused; $\mathrm{S}_{3}$ isolated by a groove; molar area with calx strongly projected. Left mandible: $S_{1}$ and $S_{2}$ teeth both separated by small incision; $S_{3}$ separated by a shallow groove. Maxilla (Figs 6, 18): Galea with two external setae and 3 internal setae, two anterior setae longer; lacinia terminates in trilobed uncus; one microseta at the base of each denticle; one row of 5 setae situated dorsally, with short median seta on the base; uncus with one basal seta situated ventrally. Stipes with a row of 6 to 15 stridulatory teeth; one long lateral seta; two anterior setae, the outer longer than inner; one small lateral microseta. Maxillary palpus 4-segmented; first segment (palpifer) with one ventral seta; second with one dorsal, one ventral and one latero-external sensilla; third with two setae and two 

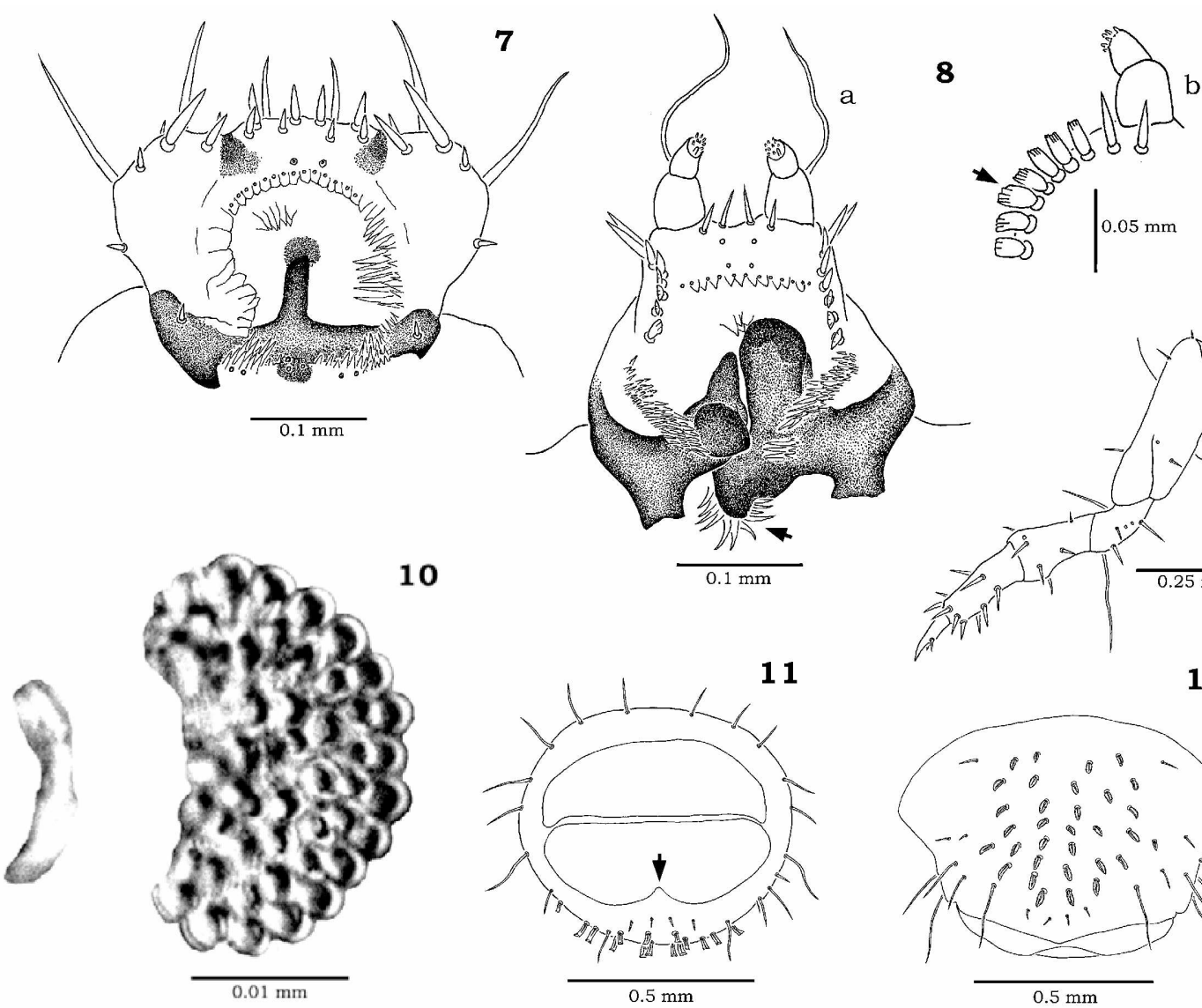

10
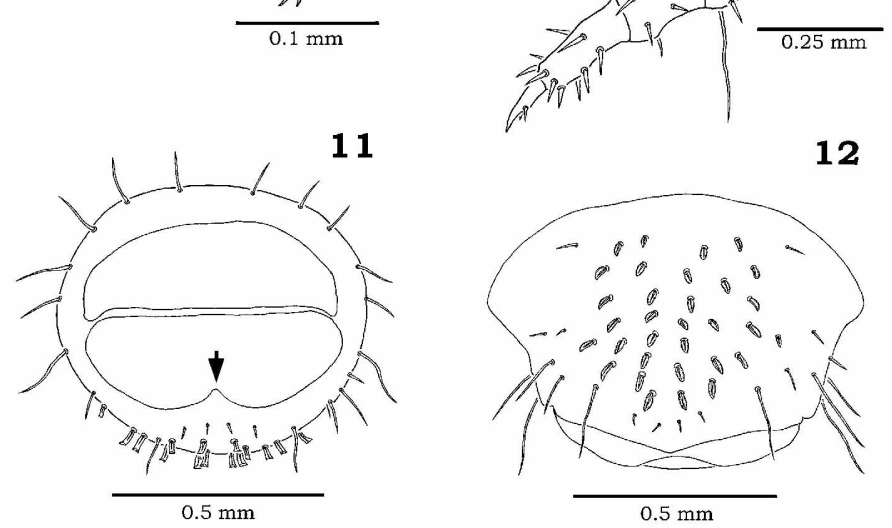

Figs 7-12: Aphodius arenarius. 7 - epipharynx; 8 - hypopharynx: a - general view (isolated group of tegumental expansions marked by arrow), $b$ - detail of glossa, lateral view (one spatula-shaped seta marked by arrow); 9 - left mesothoracic leg, posterolateral view; 10 - prothoracic spiracle; 11 - caudal view of last abdominal segment (slit marked by arrow); 12 - raster.

ventral sensilla; fourth tapering apically, with one internal seta, a sensorial longitudinal area and a distal ring of 9 short microsetae. Epipharynx (Figs 7, 19) with short anterior epitorma, broadest at apical end; pternotormae short; left pternotorma undifferentiated. Mesophoba with 3 pairs of macrosensilla covered by posterior expansions of integument. Dexiophoba slightly better developed than laeophoba. Protophoba with expansions of integument and 11 to 15 sensilla. Haptomerum with one pair of macrosensilla. Acroparia with 4 short setae. Chaetoparia with one small seta on each side. Acanthoparia with one short lateral seta. Clithra well-developed. Hypopharynx (Figs 8, 20) with asymmetrical oncyli covered in part by tegumental expansions; right oncylus posteriorly with a tuft of tegumental expansions. Glossa with two pairs of macrosensilla; lateral lobe with two pairs of setae; central lobe with 4 setae and 4 macrosensilla; posterior-lateral setae spatulate.

Thorax. Prescutum of prothorax with 12 to 14 setae of variable size. Legs (Figs 9, 21) well-developed; prothoracic pair shorter. Trochanter with two ventral macrosensilla. Femur with 2 lateral setae and a distal ring of 5 setae. Tibiotarsus with 4 ventral setae and a distal ring of 5 setae. Distal portions of tarsal claws slightly curved, with two short ventral setae.

Abdomen. Prescutum and scutum each with one transverse row of 6-8 setae. Scutellum with annulet bearing one patch of 16-18 setae. Spiracular area with 2 or 3 long setae. Ventral anal lobe may bear one shallow slit; external angles of dorsal anal lobe slightly extended to ventral anal lobe (Figs 11, 23). Raster without palidium; with one patch of 29 to 37 hamate setae (Figs 12, 24).

\section{Aphodius (Plagiogonus) arenarius (Olivier, 1789)}

Head. First antennal segment 1.7 times longer than second (Fig. 3). Glossae of hypopharynx with a row of 7-8 posterolateral setae on each side (Fig. 8).

Thorax. Size of respiratory plate of prothoracic spiracle is $34.0 \times 14.2 \mu \mathrm{m}$; with a maximum of 4 holes along any diameter (Fig. 10).

Abdomen. Ventral anal lobe with one shallow slit; external angles of dorsal anal lobe slightly extended to ventral anal lobe (Fig. 11).

Material examined. 11 third-instar larvae from adults collected at Sierra de la Carrasqueta (UTM: 30SYH1978; 1,020 m a.s.l. supramediterranean bioclimate), Alicante (Spain), 11.ii.1996, J.R. Verdú leg. (CEUA).

Biology. A total of 82 adults were captured during the sampling periods. The adults of $A$. arenarius are active from the beginning of March until the middle of June (Fig. 25). Maximum activity is in March (42.7\%). Oviposition occurs in March, preferably in rabbit latrines. First larvae occur in mid-March and larval development continues until June. The entire larval development takes 


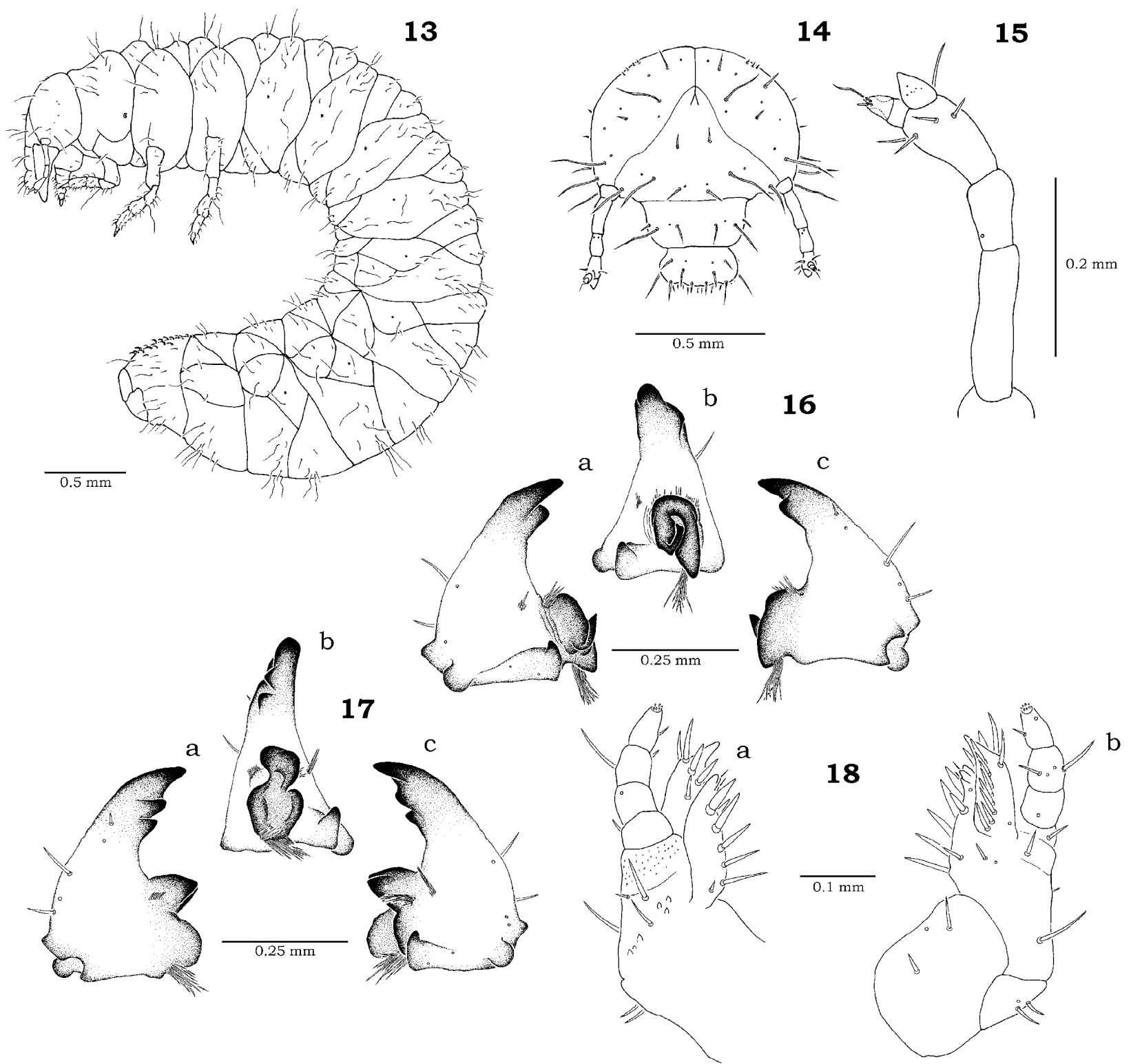

Figs 13-18: Aphodius nanus. 13 - third-instar larva, left lateral view; 14 - head, frontal view; 15 - left antenna; 16 - right mandible: $\mathrm{a}$ - ventral, $\mathrm{b}$ - molar and c - dorsal view; 17 - left mandible: $\mathrm{a}$ - ventral, $\mathrm{b}$ - molar and $\mathrm{c}$ - dorsal view; 18 - left maxilla: $\mathrm{a}$ dorsal and $b-$ ventral view.

approximately 4 weeks. Pupation occurs at the beginning of summer (June).

The larva, during its development, does not create a permanent nest, but feeds in the interface between the soil and the dung. Generally, they tend to move horizontally and never enter the dung. Prior to pupation, the larva migrates down into the soil.

The adults of $A$. arenarius have been found in rabbit, human and cattle dung used as bait in pitfall traps. They have been also found inside the brood-balls of the geotrupid Thorectes intermedius (Costa), and the species may be facultatively kleptoparasitic.

\section{Aphodius (Plagiogonus) nanus Fairmaire, 1860}

Head. First antennal segment 2.2 times the length of second (Fig. 15). Glossae of hypopharynx with a row of 9-11 posterolateral setae on each side (Fig. 20).
Thorax. Size of the respiratory plate of prothoracic spiracle $47.5 \times 9.5 \mu \mathrm{m}$; with a maximum of 3 holes along any diameter (Fig. 22).

Abdomen. Ventral anal lobe with undifferentiated slit; external angles of dorsal anal lobe not extended to ventral anal lobe (Fig. 23).

Material examined. 8 third-instar larvae from adults collected at El Garbinet, Alicante (Spain), 13.i.1996, J.R. Verdú leg. (CEUA); 4 third-instar larvae from adults collected at Campo de Mirra (UTM: 30SXH9082; 385 m a.s.l.; mesomediterranean bioclimate), Alicante (Spain), 28.i.1996, J.R. Verdú and E. Micó leg. (CEUA).

Biology. A total of 33 adults were captured. The adults of this species are active in winter, particularly from midNovember to mid-March (Fig. 26). Maximum activity is in December (78.8\%). Oviposition occurs in December and January, preferably under tree trunks where decom- 

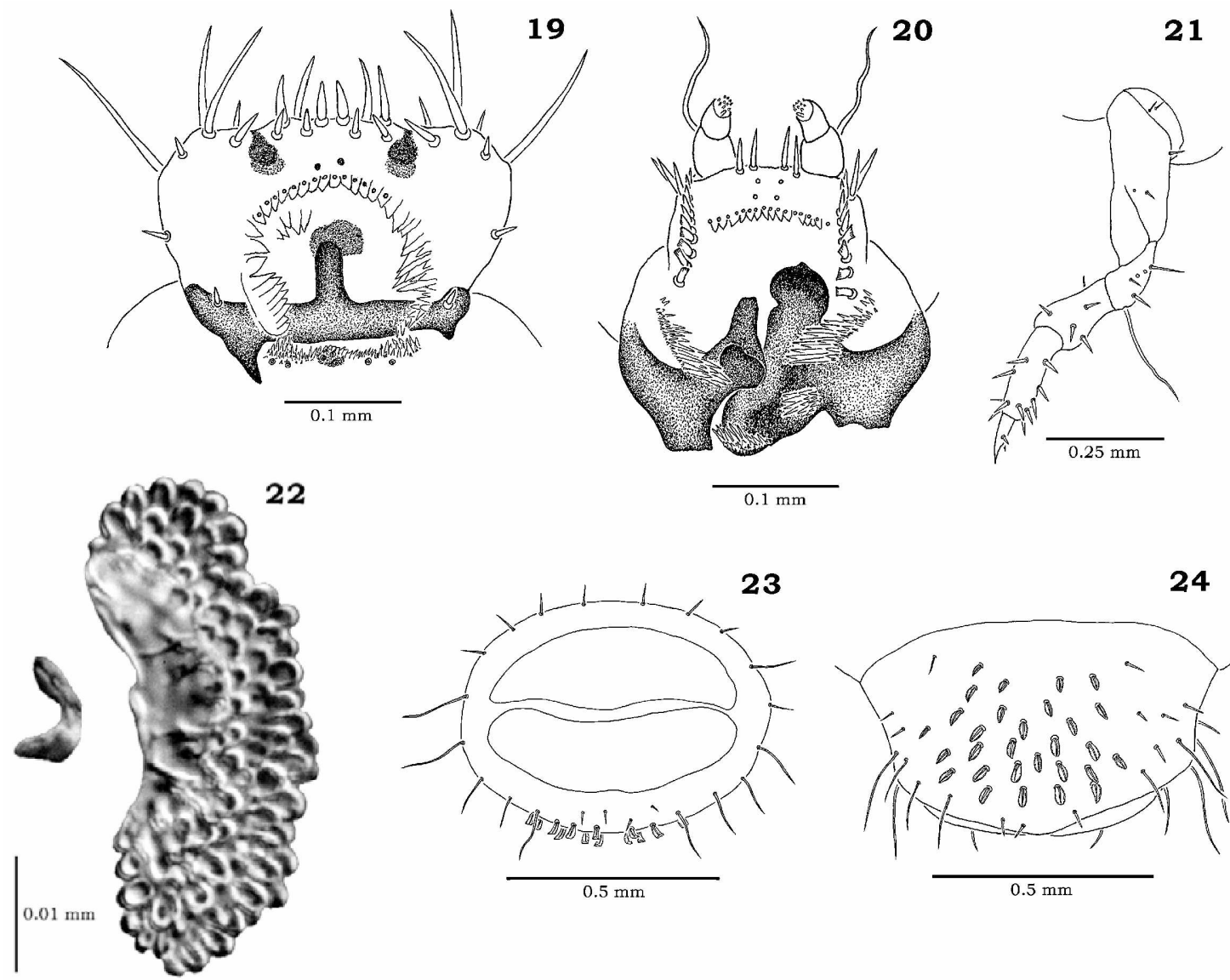

23

24
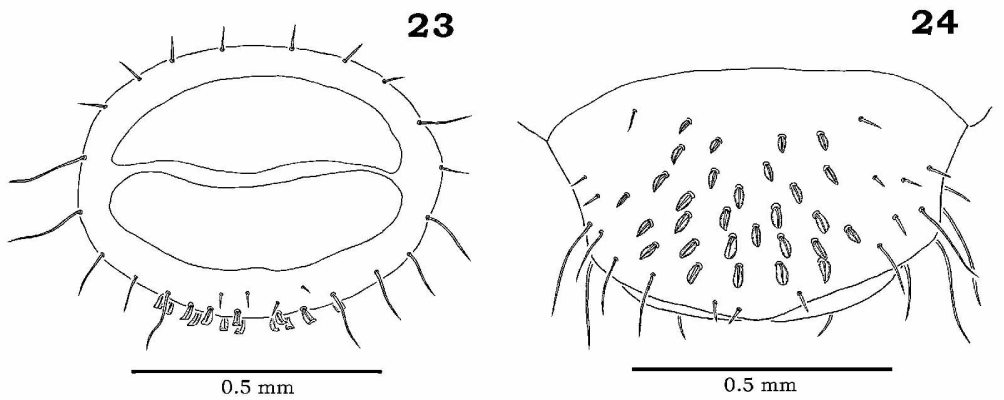

Figs 19-24: Aphodius nanus. 19 - epipharynx; 20 - hypopharynx; 21 - left mesothoracic leg, dorsal view; 22 - prothoracic spiracle; 23 - caudal view of last abdominal segment; 24 - raster.

posing leaves or manure has accumulated. The eggs are laid in the soil in groups of 5 eggs. At the end of December the first larvae hatch and development continues until March. The entire larval development takes approximately 4-6 weeks. Pupation occurs in early spring (March).

For successful development in $A$. nanus and $A$. arenarius, the larvae need to be able to move freely in the interface between the trophic resource and the soil. They never enter the dung. For pupation the larvae migrate down into the soil.

The adults of $A$. nanus have been found in various materials such as accumulations of manure, under cut wood, in dog faeces and under carrion.

\section{DISCUSSION}

\section{Larval morphology}

Plagiogonus larvae have many morphological characters, which can be used to separate the subgenera of Aphodius, such as the arrangement of the anterior setae on the stipes (Figs 6a and 18a), the spatulate form of the posterior-lateral setae on the glossae of the hypopharynx (Fig. 8b), and the development of the anal lobe slit (Figs 11 and 23). Other relevant taxonomic characters are the form of the epitorma of the epipharynx and the slight sclerotization of the pternotormae, especially the left one.
In addition, the second antennal segment is shorter than the first and third, being half the size of the first. This character was also observed by Martynov (1998) in $A$. arenarius. Finally, the posterior part of the right oncyli of the hypopharynx bears an isolated group of tegumental expansions, which have only been observed in Aphodius (Ammoecius) lusitanicus Erichson, 1848 (Verdú \& Galante, 1995).

The larva of $A$. nanus may be confused with that of Platytomus tibialis (F., 1798) because of its small size, presence in the same accumulations of manure and temporal coincidence of larval development (pers. obs.). The characters of the larva of $P$. tibialis described and illustrated by Lumaret \& Lavalette (1996) and those described here for $A$. nanus are sufficient for distinguishing both species. The presence of two upper anal lobes in $P$. tibialis, instead of one in $A$. nanus, is a particularly suitable and easily accessible character.

The most relevant diagnostic characters of Plagiogonus species are summarized in the following key:

1 Ventral anal lobe with one shallow slit (Fig. 11). First antennal segment 1.7 times the length of the second (Fig. 3). Respiratory plate subcircular, with a maximum of 4 holes along any diameter (Fig. 10). Glossae of hypopharynx with a row of 7-8 posterolateral setae on each side (Fig. 8) ... 

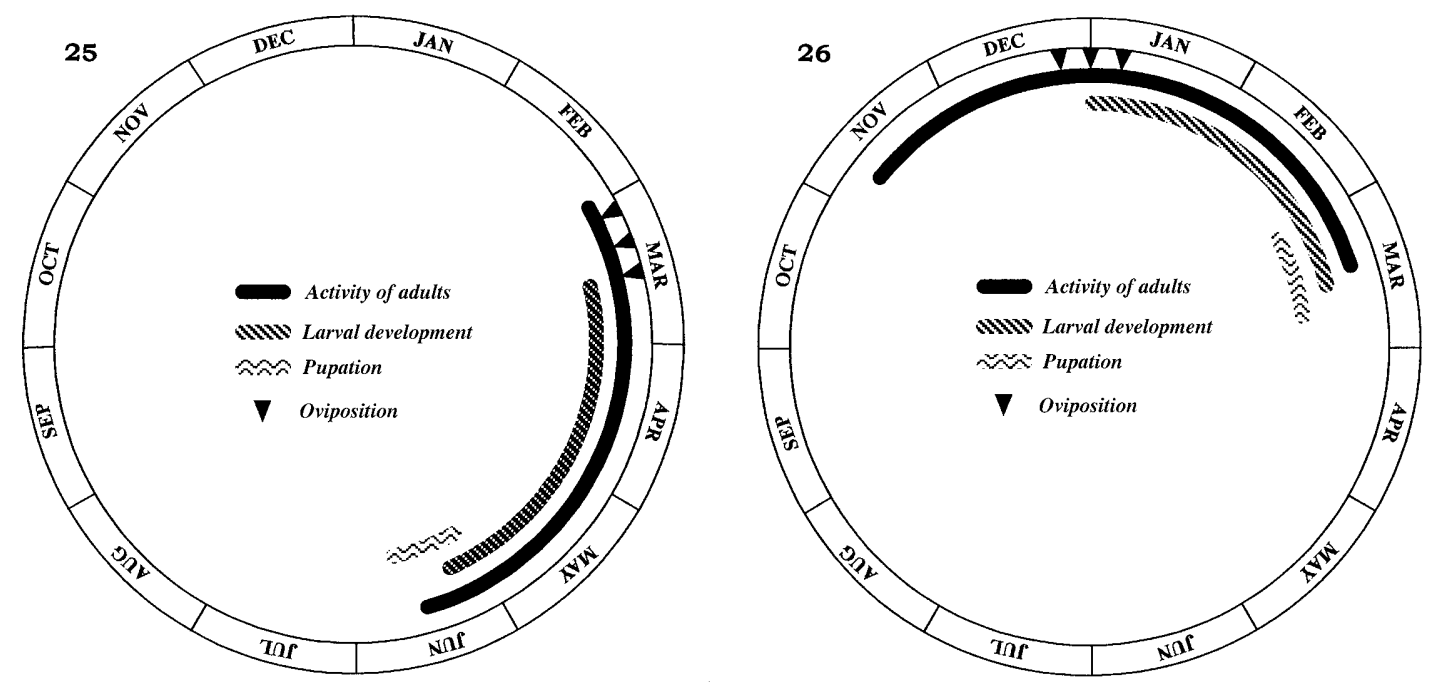

Figs 25 and 26: Life history. 25 - Aphodius arenarius; 26 - Aphodius nanus.

- Ventral anal lobe without a slit (Fig. 23). First antennal segment 2.2 times the length of the second (Fig. 15). Respiratory plate strongly elongated, with a maximum of 3 holes along any diameter (Fig. 22). Glossae with a row of 9-11 posterior-lateral setae on each side (Fig. 20) . . . A. nanus

\section{Biology}

The trophic habits of the subgenus Plagiogonus are not typical of Aphodius (Cambefort, 1991). The data obtained in this study show that $A$. arenarius and $A$. nanus have habits closer to saprophagy than to coprophagy. The dung exploited by these species tends to be dry or has a texture and chemical composition close to that of decomposing leaves, conditions often found in piles of manure and in rabbit dung (Verdú, 1998). Panin (1957) reports $A$. arenarius exploiting the faecal pellets of Marmota bobac and Citellus sp. (Rodentia) inside their burrows. Machatschke (1969) and Dellacasa (1983) also record this species in piles of cattle, horse and sheep manure. Another Plagiogonus species, $A$. (P.) ramamiensis Stebnicka, 1981 was found in cut wood and ex-river debris (Stebnicka, 1989).

The laying of groups of eggs in the soil by $A$. nanus has also been observed in $A$. arenarius (Martynov, 1998). This is rarely observed in Aphodius species (Cambefort, 1991; pers. obs.) and is more characteristic of saprophagous species belonging to Eupariini and Psammodiini (Kim \& Lumaret, 1981; pers. obs.). The larvae of Plagiogonus do not make nests as do some of the strictly coprophagous species that feed in wet dung such as Aphodius (Coprimorphus) scrutator (Herbst, 1789) (Barbero \& Palestrini, 1995). In contrast, Plagiogonus larvae prefer to feed on dry dung and live at the interface between the food and the soil. This has also been observed in other Aphodius species exploiting rabbit dung, such as $A$. (Nobius) bonnairei Reitter, 1982 and A. (Ammoecius) lusitanicus (Galante, 1990; Verdú \& Galante, 1995), other types of dry dung, such as A. (Agolius) abdominalis Bonelli, 1812 (Lumaret \& Stiernet, 1984), or piles of manure, such as $A$. (Calamosternus) granarius (L., 1767) and $A$. (C.) hyxos Petrovitz, 1962 (Verdú et al., 1997). In the saprophagous species belonging to the Eupariini and Psammodiini this feeding behaviour is typical (Kim \& Lumaret, 1981; Lumaret \& Lavalette, 1996; pers. obs.).

ACKNOWLEDGEMENTS. We are indebted to Z. Stebnicka for her valuable critique of the manuscript. K. Burke and M. Sánchez checked the English version. This research was supported by the Generalitat Valenciana, Spain (GV-C-RN-12-069-96).

\section{REFERENCES}

BÁguena L. 1967: Scarabaeoidea de la Fauna Ibero-Balear y Pirenaica. Consejo Superior de Investigaciones Científicas, Instituto Español de Entomología, Madrid, 576 pp.

Baraud J. 1977: Coléoptères Scarabaeoidea. Faune de l'Europe occidentale. Nouvelle Revue d'Entomologie, Toulouse, $352 \mathrm{pp}$.

Barbero E. \& Palestrini C. 1995: Aphodius (Coprimorphus) scrutator. Descrizione della larva e note di biologia riproduttiva. Fragm. Entomol. 26: 341-352.

CAMBeForT Y. 1991: From saprophagy to coprophagy. In Hanski I. \& Cambefort Y. (eds): Dung Beetle Ecology. Princeton University Press, Princeton, New Jersey, pp. 22-35.

Dellacasa G. 1983: Sistematica e nomenclatura degli Aphodiini italiani (Coleoptera: Scarabaeidae: Aphodiinae). Museo Regionale di Scienze Naturali, Torino, $463 \mathrm{pp}$.

Galante E. 1990: La larve d'Aphodius (Nobius) bonnairei Reitter, 1892 et données sur sa biologie (Coleoptera, Scarabaeoidea, Aphodiidae). Nouv. Rev. Entomol. (N.S.) 7: 283-288.

KIM J.I. \& Lumaret J.P. 1981: Écologie de Psammodius porcicollis (III.) (Col. Aphodiidae), insecte sabulicole des dunes littorales du Golfe du Lion. Ann. Soc. Entomol. Fr. (N.S.) 17: 449-462.

Kim J.I. \& Lumaret J.P. 1988: Deuxième contribution à l'étude des Aphodiidae de Corée (Coleoptera, Scarabaeoidea). Nouv. Rev. Entomol. (N.S.) 5: 159-172.

LuMARET J.P. 1978: Biogéographie et écologie des Scarabéides coprophages du sud de la France. Thèse doctorat d'Etat. Montpellier I, $254 \mathrm{pp}$.

Lumaret J.P. 1990: Atlas des Coléoptères Scarabéides Laparosticti de France. Inventaires de la Faune et de la Flore. Fasc. 1. Muséum national d'Histoire naturelle, Paris, 419 pp. 
Lumaret J.P. \& Lavalette F. 1996: Biology and description of the larva of Platytomus tibialis (Coleoptera: Aphodiidae: Rhyssemina). Acta Soc. Zool. Bohem. 60: 385-389.

Lumaret J.P. \& Stiernet N. 1984: Contribution à l'étude de la faune des alpes suisses. Description de la larve d'Aphodius (Agolius) abdominalis Bonelli, 1812 (Coleoptera, Aphodiidae). Bull. Soc. Entomol. Suisse 57: 335-340.

MACHATSCHKE J.W. 1969: Lamellicornia - Scarabaeidae (Blatthornkäfer). In Freude H., Harde K.W. \& LoHSE G.A. (eds): Die Käfer Mitteleuropas 8 . Goecke \& Evers, Krefeld, pp. 265-388.

Martynov V.V. 1998: A description of the larvae of three beetle species of the genus Aphodius (Coleoptera, Scarabaeidae). Communication 1. Vestnik Zool. 32(5-6): 39-46.

Mena J., Galante E. \& Lumbreras C.J. 1989: Daily flight activity of Scarabaeidae and Geotrupidae (Col.) and analysis of the factors determining this activity. Ecol. Mediterranea 15(1/2): 69-80.

Panin S. 1957: Fauna Republicii Populare Romîne, Coleoptera Familia Scarabaeidae, X, 4, subfam. 3 Aphodiinae. Academiei Republicii Populare Romîne, BucureÕti, 315 pp., 36 pl.
RITCher P.O. 1966: White Grubs and Their Allies. Studies in Entomology. No. 4. Oregon State University Press, Corvallis, Oregon, $219 \mathrm{pp}$.

SteBnicKa Z. 1989: Revision of the Aphodiinae of the Western Himalayas (Coleoptera: Scarabaeidae). Stuttg. Beitr. Naturk. (Ser. A, Biologie) No. 441, 29 pp.

VERDÚ J.R. 1998: Biología de los escarabeidos coprófagos en ecosistemas iberolevantinos. Ecología y análisis biogeográfico (Coleoptera, Scarabaeoidea). Tesis Doctoral, Universidad de Alicante, Alicante, $393 \mathrm{pp}$.

VeRDư J.R. \& Galante E. 1995: Life history and description of the larval stage of Aphodius lusitanicus Erichson, 1848 (Coleoptera: Scarabaeoidea: Aphodiidae). Acta Zool. Cracov. 38: 205-212.

Verdú J.R. \& Galante E. 1997: Aphodius brasiliensis Castelnau (Coleoptera: Aphodiidae). Larval morphology and notes on biology. Coleopt. Bull. 51: 378-383.

Verdú J.R., Lumaret J.P. \& Galante E. 1997: Biology of Aphodius hyxos Petrovitz (Coleoptera: Scarabaeoidea: Aphodiidae) and description of the third larval stage. Can. Entomol. 129: 657-667.

Received September 8, 1999; accepted March 28, 2000 